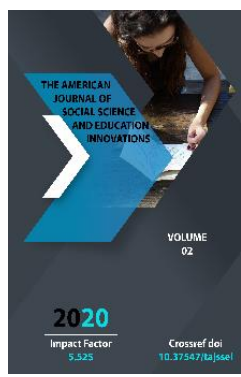

\title{
The Role Of Pedagogy In The Promotion Of National And Cultural Heritage
}

\author{
Nurboeva Habiba Botirovna \\ Teacher Of The Department Of Pedagogy And Psychology, Methodologist At The Department \\ Of Spirituality And Enlightenment Of The National University Of Uzbekistan
}

Copyright: Original content from this work may be used under the terms of the creative commons attributes 4.o licence.

\section{ABSTRACT}

Cultural and national examinations appears to have passed into the shadows of scholarly interests, supplanted by globalization and political economy as the new thousand years' special worries among left scholastics. However, social and public examinations' longstanding interest in the interrelationship of intensity, legislative issues, and culture remains basically significant. Matters of organization, awareness, instructional method, and way of talking are fundamental to any open talk about legislative issues, also schooling itself. Henceforth, this article contends that the guarantee of social examinations, particularly as a principal part of advanced education, dwells in a bigger groundbreaking and majority rule legislative issues in which matters of teaching method and office assume a focal job.

\section{KEYWORDS}

Pedagogy, culture, national heritage, educator, education, disciplinary, responsibility.

\section{INTRODUCTION}

Pedagogy is an encompassing term concerned with what a teacher does to influence learning in others. As the importance of high quality early childhood education and care services for children has become more clearly understood, so has the teacher/educator's role in the provision of these services. This demands a clear understanding of the meaning of 'pedagogy' and how it plays out in individual educators and services. The definitions below 
show a range of thinking around the term pedagogy, all of which have what a teacher does and how they do it at their core. For the purpose of this document the terms 'teacher' and 'educator' are used interchangeably. Pedagogy is about learning, teaching and development influenced by the cultural, social and political values we have for children... in Scotland, and underpinned by a strong theoretical and practical base. Quality teaching is defined as pedagogical practices that facilitate for diverse children their access to knowledge, activities and opportunities to advance their skills in ways that build on previous learning, assist in learning how to learn and provide a strong foundation for further learning in relation to the goals of the early childhood curriculum. Pedagogy develops from a range of factors including theories and research evidence, political drivers, evidence from practice, individual and group reflection, educators' experiences and expertise, and community expectations and requirements. It informs both curriculum (all the interactions, experiences, activities, routines and events planned and unplanned) and teaching in a service. It reflects and supports the principles of and outcomes sought by a service.

Early years' pedagogy is an extremely complex phenomenon comprising a wide variety of practices underpinned by principles acquired through training and as a result of professional experiences and personal understandings. Because of its complexity 'effectiveness' has to be viewed as a whole rather than as particular aspects taken in isolation. Early childhood education and care is concerned with ensuring children achieve positive outcomes. Research on teaching, learning and outcomes shows that quality pedagogy is identified as a key lever for improving children's outcomes. Sound research evidence, discussed later, shows what educators can do to provide children with strong foundations for ongoing learning and development in all aspects of life. This evidence must be reflected in educators' pedagogy if children's learning and development is to be optimized.

\section{METHODOLOGY}

Pedagogy evolves through ongoing research and reflection at all levels, including service and educator level. This ensures continuous improvement in educators' practice with the aim of supporting the best possible outcomes for all children and recognizes the importance of the educator in children's learning and development.

\section{RESEARCH WORKS}

Within the last few decades, a number of critical and cultural and national studies have been provided to our understanding of how culture deploys power and is shaped and organized within diverse systems of representation, production, consumption, and distribution. Culture is recognized as the social field where goods and social practices are not only produced, distributed, and consumed but also invested with various meanings and ideologies implicated in the generation of political effects. Culture is partly defined as a circuit of power, ideologies, and values in which diverse images and sounds are produced and circulated, identities are constructed, inhabited, and discarded, agency is man fested in both individualized and social forms, and discourses are created, whichmake culture itself the object of inquiry and critical analyses. Rather than beingviewed as a static force, the substance of culture and everyday lifeknowledge,goods, social practices, and 
contexts-repeatedly mutates and is subject to ongoingchanges and interpretations. Within this discourse, cultural studies becomes available as a resource to educators Cultural studies, pedagogy, and responsibility who can then teach students how to look at the media (industry and texts), analyzeaudience reception, challenge rigid disciplinary boundaries, critically engage popularculture, produce critical knowledge, or use cultural studies to reform the curriculaand challenge disciplinary formations within public schools and higher education.In spite of the importance of bringing matters of culture and power tothe schools, I think too many cultural studies theorists are remiss in suggesting thatpedagogy is primarily about schools and, by implication, that the intersection ofcultural studies and pedagogy has little to do with theorizing the role pedagogymight play in linking learning to social change outside of traditional sites ofschooling.6Pedagogy is not simply about the social construction of knowledge,values, and experiences; it is also a performative practice embodied in the livedinteractions among educators, audiences, texts, and institutional formations. Pedagogy, at its best, implies that learning takes place across a spectrum of social practicesand settings. As Roger Simon observes, pedagogy points to the multiplicity of sitesin which education takes place and offers the possibility for a variety of culturalworkersto comprehend the full range of multiple, shifting and overlapping sites of learningthat exist within the organized social relations of everyday life. This means being able to grasp, for example, how workplaces, families, community and institutional health provision, film and television, the arts, groups organized for spiritual expression and worship, organized sport, the law and the provision of legal services, the prison system, voluntary social service organizations, and community based literacy programs. Moreover, it is precisely at the intersection at which diverse traditions in cultural studies and pedagogy mutually inform each other that the possibility exists of making the pedagogical more political for cultural studies theorists and the political more pedagogical for educators. An interest in cultural studies emerges from an ongoing project to theorize theregulatory and emancipatory relationship among culture, power, and politics as expressed through the dynamics of what I call public pedagogy. Culture, in this instance, is the ground of both contestation and accommodation, and it is increasingly characterized by the rise of megacorporationsand new technologies that are transforming the traditional spheres of the economy, industry, society, and everyday life. Culture now plays a central role in producing narratives, metaphors, and images that exercise a powerful pedagogical force overhow people think of themselves and their relationship to others. From my perspective, culture is the primary sphere in which individuals, groups, and institutions engage in the art of translating the diverse and multiple relations that mediate between private life and public concerns. It is also the sphere in which the translating possibilities of culture are under assault, particularly as the forces of neoliberalism dissolve public issues into utterly privatized and individualistic concerns. Central to my work in cultural studies is the assumption that the primacy of culture and power should be organized through an understanding of how the political becomes pedagogical, particularly in terms of how private issues areconnected to larger social conditions and collective forces-that is, how the very processes of learning constitute the political 
mechanisms through which identitiesare shaped and desires mobilized, and how experiences take on form and meaning.

\section{RESULTS}

Cultural studies, pedagogy, and responsibility within and through collective conditions and those larger forces that constitute therealm of the social. In this context, pedagogy is no longer restricted to what goes onin schools, but becomes a defining principle of a wide ranging set of cultural apparatuses engaged. The realm in the latter part of the twentieth century because the actualityof economic power and its attendant networks of control now exercised moreinfluence than ever before in shaping how identities are produced, desires mobilized,and everyday social relations acquired the force of common sense. Pedagogy is a referent for understanding the conditions of critical learning and the often hidden dynamics of social and cultural reproduction. As a critical practice, pedagogy's role lies not only in changing how people think about themselves and how they behave. But like any other body of knowledge that is continuously struggled over, pedagogymust constantly enter into dialogue with other fields, theoretical domains, andemerging theoretical discourses. As diverse as cultural studies is as a field, there area number of insights it provides that are crucial to educators who use criticalpedagogy both inside and outside of their classrooms. First, in the face of contemporary forms of political and epistemological relativism, a more politicized version of cultural studies makes a claim for the use ofhighly disciplined, rigorously theoretical work. Not only does such a position rejectthe notion that intellectual authority can only be grounded in particular forms ofsocial identity, but it also refuses to endorse an increasing anti-intellectualism thatposits theory as too academic and complex to be of any use in addressing importantpolitical issues. While many cultural studies advocates refuse either to separateculture studies from politics or reject theory as too complex and abstract, they alsoreject theory as a sterile form of theoreticizm and an academicized vocabulary thatis as self-consciously pedantic as it is politically irrelevant. Matters of language,experience, power, ideology, and representation cannot make a detour aroundtheory, but that is no excuse for elevating theory to an ethereal realm that has noreferent outside of its own obtuseness or rhetorical cleverness. While offering noguarantees, theory in a more critical perspective is seen as crucial for relating broaderissues of politics and power to the problems that shape everyday life. Moreover,theory in this view is called upon as a resource for connecting cultural studies tothose sites and spheres of contestation in which it becomes possible to open uprhetorical and pedagogical spaces between the actual conditions of dominant powerand the promise of future space informed by a range of democratic alternatives. Underlying such a project is a firm commitment to intellectual rigor and a deepregard for matters of compassion and social responsibility aimed at deepening andextending the possibilities for critical agency, racial justice, economic democracy,and the just distribution of political power. Hence, cultural studies theorists oftenreject the anti-intellectualism, specialization, and methodological reification frequently found in other disciplines. Similarly, such theorists also reject both theuniversalizing dogmatism of some strands of radical theory and a postmodernepistemology that enshrines 
difference, identity, and plurality at the expense ofdeveloping more inclusive notions of the social that bring together historically andpolitically differentiated forms of struggles. The more progressive strains of culturalstudies do not define or value theory and knowledge within sectarian ideological orpedagogical interests. On the contrary, these approaches to cultural studies definetheorizing as part of a more generalized notion of freedom, which combinesdemocratic principles, values, and practices with the rights and discourses that buildon the histories and struggles of those excluded because of class, race, gender, age,or disability. Theory emerges from the demands posed by particular contexts, andreflects critically upon ways both to better understand the world and to transformit when necessary.At the same time, it is crucial for educatorsto recognize that while they need to be attentive to the particular context in whichthey work, they cannot separate such contexts from larger matters andconfigurations of power, culture, ideology, politics, and domination.

\section{CONCLUSION}

One implication for such work is that future and existing teachersshould be educated about the viability of developing contextdependent learning thattakes account of student experiences and their relationships to popular culture andits terrain of pleasure, including those cultural industries that are often dismissed asproducing mere entertainment. Despite the growing diversity of students in bothpublic schools and higher education, there are few examples of curriculum sensitivityto the multiplicity of economic, social, and cultural factors bearing on students' lives.Even where there is a proliferation of programs such as ethnic and black studies inhigher education, these are often marginalized in small programs far removed fromthe high status courses such as business, computer science, and Western history.Cultural studies at least provides the theoretical tools for allowing teachers torecognize the important, though not unproblematic, cultural resources studentsbring to school and the willingness to affirm and engage them critically as forms ofknowledge crucial to the production of the students' sense of identity, place, andhistory. Equally important, the knowledge produced by students offers educatorsopportunities to learn from young people and to incorporate such knowledge as anintegral part of their own teaching. Yet, there is an important caveat that cannot bestated too strongly.

Cultural studies, pedagogy, and responsibility approach is also important because such work often operates at the frontiers ofknowledge, prompting teachers and students to raise new questions and developmodels of analysis outside of the officially sanctioned boundaries of knowledge andthe established disciplines that sanction them. Trans-disciplinarity in this discourse serves a dual function. On the one hand, it firmly posits the arbitrary conditionsunder which knowledge is produced and encoded, stressing its historically andsocially constructed nature and deeply entrenched connection to power and ideological interests. On the other hand, it endorses the relational nature of knowledge,inveighing against any presupposition that knowledge, events, and issues are eitherfixed or should be studied in isolation. Trans-disciplinary approaches stress both historical relations and broader social formations, always attentive to new linkages,meanings, and possibilities. 
Strategically and pedagogically, these modes of analysissuggest that while educators may be forced to work within academic disciplines, theycan develop trans-disciplinary tools to make established disciplines the object ofcritique while also contesting the broader economic, political, and cultural conditions that reproduce unequal relations of power and inequities at various levels ofacademic work. This is a crucial turn theoretically and politically because transdisciplinary approaches foreground the necessity of bridging the work educators dowithin the academy to other academic fields as well as to public spheres outside ofthe university. Such approaches also suggest that educators function as publicintellectuals by engaging in ongoing public conversations that cut across particulardisciplines while attempting to get their ideas out to more than one type of audience.Under such circumstances, educators must address the task of learning the forms ofknowledge and skills that enable them to speak critically and broadly on a numberof issues to a wide range of publics.Fourth, in a somewhat related way, the emphasis by many cultural studiestheorists on studying the full range of cultural practices that circulate in societyopens the possibility for understanding a wide variety of new cultural forms thathave become the primary educational forces in advanced industrial societies. Thisseems especially important at a time when new electronic technologies and theemergence of visual culture as a primary educational force offer new opportunitiesto inhabit knowledge and ways of knowing that simply do not correspond to thelongstanding traditions and officially sanctioned rules of disciplinary knowledge orof the one-sided academic emphasis on print culture. The scope and power of newinformational technologies, multimedia, and visual culture warrant educators tobecome more reflective about engaging the production, reception, and situated useof new technologies, popular texts, and diverse forms of visual culture, includinghow they structure social relations, values, particular notions of community, thefuture, and varied definitions of the self and others. Texts in this sense do not merelyrefer to the culture of print or the technology of the book, but refer to all thoseaudio, visual, and electronically mediated forms of knowledge that have prompted aradical shift in the production of knowledge and the ways in which it is received and consumed.

Cultural studies, pedagogy, and responsibility as a process that never ends. Such a project is based on the realization that ademocracy open to exchange, question, and self-criticism never reaches the limits ofjustice; it is never just enough and never finished. It is precisely the open-ended andnormative nature of such a project that provides a common ground for culturalstudies theorists to share their differences and diverse range of intellectual pursuits.Second, cultural studies is still largely an academic discourse and as such is oftentoo far removed from other cultural and political sites where the work of publicpedagogy takes place. In order to become a public discourse of any importance,cultural studies theorists will have to focus their work on the immediacy of problemsthat are more public and that are relevant to important social issues. Such issuesmight include the destruction of the ecological biosphere, the current war againstyouth, the hegemony of neo-liberal globalization, the widespread attack by corporateculture on public schools, the ongoing attack on the welfare system, the increasingrates of incarceration of people of 
color, the increasing gap between the rich and thepoor, the increasing spread of war globally, or the dangerous growth of theprisonindustrial complex. Moreover, cultural studies theorists need to write for avariety of public audiences, rather than for simply a narrow group of specializedintellectuals. Such writing needs to become public by crossing over into sites andavenues of expression that speak to more general audiences in a language that is clearbut not theoretically simplistic. Intellectuals must combine their scholarship withcommitment in a discourse that is not dull or obtuse but expands the reach of theiraudience. This suggests using opportunities offered by a host of public means ofexpression including the lecture circuit, radio, Internet, interview, alternativemagazines, and the church pulpit, to name only a few.Third, cultural studies theorists need to be more specific about what it wouldmean to be both self-critical and attentive to learning how to work collectivelythrough a vast array of networks across a number of public spheres.

Pedagogy in this instance can beaddressed as a moral and political discourse in which students are able to connectlearning to social change, scholarship to commitment, and classroom knowledge topublic life. Such a pedagogical task suggests that educators and cultural theoristsdefine intellectual practice as part of "an intricate web of morality, rigor andresponsibility" that enables them to speak with conviction, enter the public spherein order to address important social problems, and demonstrate alternative modelsfor what it means to bridge the gap between higher education and the broader society. One useful approach is for educators to think through the distinctionbetween a politicizing pedagogy, which insists wrongly that students think as we do,and a political pedagogy, which teaches students by example the importance oftaking a stand (without standing still) while rigorously engaging the full range ofideas about an issue. Political pedagogy connects understanding with the issue ofsocial responsibility and what it would mean to educate students not only to engagethe world critically but also to be responsible enough to fight for those political andeconomic conditions that make its democratic possibilities viable. Such a pedagogyaffirms the experience of the social and the obligations it evokes regarding questionsof responsibility and social transformation by opening up for students importantquestions about power, knowledge, and what it might mean for them to criticallyengage the conditions under which life is presented to them and simultaneouslywork to overcome those social relations of oppression that make living unbearablefor those who are poor, hungry, unemployed, deprived of adequate social services,and viewed under the aegis of neo-liberalism as largely disposable. What is import-ant about this type of critical pedagogy is the issue of responsibility as both anormative issue and a strategic act. Responsibility highlights not only the performative nature of pedagogy by raising questions about the relationship that teachers haveto students but also the relationship that students have to themselves and others.Central here is the importance for cultural studies educators to encourage studentsto reflect on what it would mean for them to connect knowledge and criticism tobecoming an actor, buttressed by a profound desire to overcome injustice and aspirited commitment to social agency. Political education teaches students to takerisks, challenge those with power, and 
encourage them to be reflexive about howpower is used in the classroom. Political education proposes that the role of thepublic intellectual is not to consolidate authority but to question and interrogate it,and that teachers and students should temper any reference for authority with asense of critical awareness and an acute willingness to hold it accountable for itsconsequences. Moreover, political education foregrounds education not within theimperatives of specialization and professionalization, but within a project designedto expand the possibilities of democracy by linking education to modes of politicalagency that promote critical citizenship and engage the ethical imperative to alleviatehuman suffering. However, politicizing education silences in the name of orthodoxyand imposes itself on students while undermining dialogue, deliberation, and critical

\section{REFERENCES}

1. Moyles, J., Adams, S. \& Musgrove, A. (2002). Brief No: RB363, Study of PedagogicalEffectiveness in Early Learning. Anglia Polytechnic University.

2. Wood, E. (2004). Developing a pedagogy of play in A. Anning, J. Cullen \& M. Fleer (eds).Early Childhood Education: Society and Culture. London: Sage.

3. See, for example, Douglas Kellner, Media Culture: Cultural Studies, Identity, and Politics(New York: Routledge, 1995).

4. Roger Simon, "Broadening the Vision of University-Based Study of Education: TheContribution of Cultural Studies" The Review of Education/Pedagogy/Cultural Studies 12, no.1 (1995): 109. 